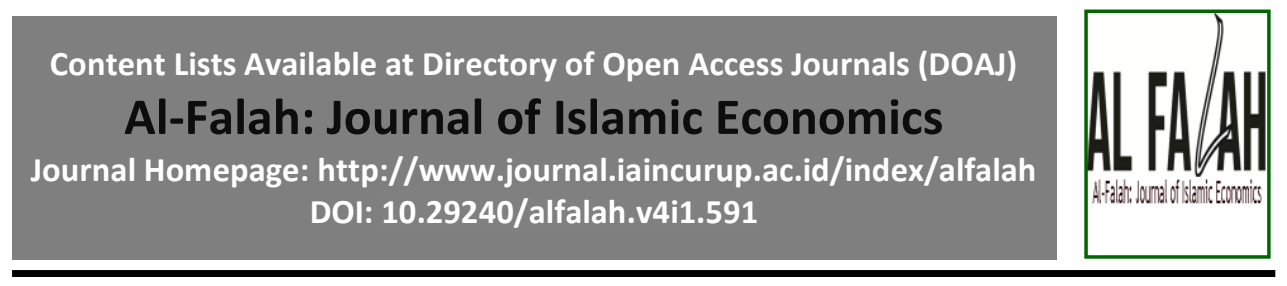

\title{
Timur Tengah dan Ekonomi Syariah: Studi Empiris Terhadap Perkembangan Ekonomi Syariah di Timur Tengah
}

\author{
Nur Azizah Latifah ${ }^{\mathrm{a}^{*}}$; Mulyono Jamal ${ }^{\mathrm{b}}$ \\ ${ }^{a b}$ Pascasarjana Universitas Darussalam Gontor, Jawa Timur, Indonesia \\ "Email Address: nurazizablatifah418@gmail.com
}

\begin{tabular}{l}
\hline ARTICLE INFO \\
\hline Article History: \\
Received 22-03-2019 \\
Revised 28-03-2019 \\
Accepted 16-05-2019 \\
\hline Keywords: \\
Ekonomi Syariah \\
Era Minyak \\
OAPEC \\
Jalur Timur \\
Khalifah \\
\hline Paper Type: \\
Viewpoint
\end{tabular}

\begin{abstract}
Purpose: This study is intended to identify how the practice and development of Islamic economics in the Middle East - the Arabian Peninsula.

Design / Method / Approach : This study begins with a process of historical reading of economic activity and how the Islamic economy is the norm applied by economic institutions. In drawing conclusions, this study intensely uses historical facts as the source and foundation of conceptualization and equity of study findings.

Findings : Development of a Sharia Economy in the Middle East Before the birth of the oil era at the beginning of the 20th, the main Gulf region was on the southern coast, acting as a liaison to Indian markets from the West and Somalia from the East. One of them is Aden, a natural port of Yemen, where ships from Ethiopia and India dock. The eastern path through the coast of the southern Arabian peninsula and up to the Persian bay is a link through the sea from Yemen to Iraq and transmits by land to Sham. On the track, traders crossed the Yemeni, Iraqi, Palmyra and Syrian markets. In each region they sell commodities that are not there and also buy commodities in the region to be brought to other regions. Because of a number of factors, for the time being, the economic development of the region is arguably stagnant and escaped world attention. Along with the development of science and technology in the early twentieth century, the need for fuel oil began to increase.

Originality /Novelty: This article is not only a reference, but also a copy that can be used as a historical foundation to understand the development of Islamic economics in Middle Eastern friends.
\end{abstract}

\footnotetext{
ABSTRAK

Tujuan: Kajian ini ditujukan untuk mengidentifikasi bagaimana praktek dan perkembangan ekonomi syariah di Timur Tengahjazirah Arab.

Desain/Metode/Pendekatan : Kajian ini dimulai dengan proses pembacaan historis terhadap aktivitas ekonomi dan bagaimana ekonomi Islam sebagai norma diterapkan oleh institusi ekonomi.
} 


\begin{abstract}
Dalam menarik kesimpulan, kajian ini intens menggunakan fakta sejarah sebagai sumber dan fondasi konseptualisasi dan penteorian temuan kajian.

Temuan : Perkembangan Ekonomi Syariah di Timur Tengah Sebelum lahirnya era minyak pada awal ke-20, kawasan Teluk utamanya di pesisir pantai selatan, berperan sebagai jalur penghubung ke pasar-pasar India dari Barat dan Somalia dari Timur. Salah satunya Aden, sebuah pelabuhan alamiah Yaman, di mana kapal-kapal dari Ethiopia dan India berlabuh. Jalur timur melalui pesisir pantai semenanjung Arab bagian selatan dan hingga teluk Persia merupakan jalur penguhubung melalui lautan dari Yaman ke Irak dan menerukan melalui darat ke Syam. Di jalur itu, para pedagang melintasi pasarpasar Yaman, Irak, Palmyra, dan Syiria. Di setiap wilayah mereka menjual komoditas yang tidak ada di sana dan juga membeli komoditas wilayah itu untuk dibawa ke wilayah-wilayah lain. Oleh karena beberapa faktor, untuk sementara waktu, perkembangan ekonomi kawasan ini bisa dibilang stagnan dan luput dari perhatian dunia. Seiring perkembangan ilmu pengetahuan dan teknologi pada awal abad dua puluh, kebutuhan bahan bakar minyak mulai meningkat.

Originalitas/Novelty: Tulisan ini selain sebagai referensi, juga menjadi eksemplar yang dapat dijadikan sebagai landasan historis untuk memahami perkembangan ekonomi syariah di kawan Timur Tengah.
\end{abstract}

\title{
PENDAHULUAN
}

Timur Tengah adalah sebuah wilayah yang secara politis dan budaya merupakan bagian dari benua Asia, atau Afrika-Eurasia. Pusat dari wilayah ini adalah daratan di antara Laut Mediterania dan Teluk Persia serta wilayah yang memanjang dari Anatolia, Jazirah Arab dan Semenanjung Sinai. Kadangkala disebutkan juga area tersebut meliputi wilayah dari Afrika Utara di sebelah barat sampai dengan Pakistan di sebelah timur, dan Kaukasus dan/atau Asia Tengah di sebelah utara. Media, dan beberapa organisasi internasional (seperti PBB) umumnya menganggap wilayah Timur Tengah adalah wilayah Asia Barat Daya (termasuk Siprus dan Iran) ditambah dengan Mesir.

Wilayah tersebut mencakup beberapa kelompok suku dan budaya termasuk suku Iran, suku Arab, suku Yunani, suku Yahudi, suku Berber, suku Assyria, suku Kurdi, dan suku Turki. Bahasa utama yaitu: bahasa Persia, bahasa Arab, bahasa Ibrani, bahasa Assyria, bahasa Kurdi dan bahasa Turki. Kebanyakan sastra barat mendefinisikan Timur Tengah sebagai negara-negara di Asia Barat Daya, dari Iran (Persia) ke Mesir. Mesir dengan semenanjung Sinainya yang berada di Asia umumnya dianggap sebagai bagian dari Timur Tengah, walaupun sebagian besar wilayah negara itu secara geografi berada di Afrika Utara. Sejak pertengahan abad ke-20, Timur Tengah telah menjadi pusat terjadinya peristiwa-peristiwa dunia, dan menjadi wilayah yang sangat sensitif, baik dari segi kestrategisan lokasi, politik, ekonomi, kebudayaan, dan keagamaan. Timur Tengah mempunyai cadangan minyak mentah dalam jumlah 
besar, dan merupakan tempat kelahiran, dan pusat spiritual Islam, kristen, agama Yahudi. Fakta sosial dan historis ini membuat, dan mendorong para sarjana menjadikan Timur Tengah sebagai field kajian, dan kemudian menghasilkan banyak teori dan beragam corak informasi. Dalam konteks ini, perkembangan ekonomi syariah di Timur Tengah mesti dipahami dan dikaji.

Adalah Faisal Alnori, Faisal Alqathani melakukan kajian tentang Capital Structure and Speed of Adjusment in non-financial firm: Does Sharia Complience Matter? Evidence from Saudia Arabia, mereka berhasil mengidentifikasi dampak dari kepatuhan terhadap nilai-nilai syariah pada struktur kapital dalam sebuah perusahaan, dan dampaknya terhadap speed of adjusment in non financial firms pada pasar Arab Saudi dari tahun 2005 hingga 2016. ${ }^{1}$ Ini bermakna bahwa nilai-nilai syariah di Arab Saudi telah menjadi apa yang disebut dengan institutionalizednorm, atau norma yang terinstitusionalisasi dalam aktivitas sosial, ekonomi dan politik bangsa Arab.

T. Kenn Geither, Ali Jamal Al-Kandari dengan tulisan yang lebih spesifik merujuk Bank Islam, juga melakukan kajian yang mendalam bagaimana bank syariah di Kuwait sebagai sebuah model. Kendati mereka membahas model ekonomi kultural dan public relations, serta berhasil mengidentifikasi bahwa perkembangan bank syariah di Kuwait tidak terlepas dari peran profesional muslim yang sangat concern dalam menerapkan model kultural ekonomi, yang bersumber dari nilai-nilai Islam dan budaya Arab. ${ }^{2}$ Kajian Geither, Al-Kandari ini tidak hanya menginformasikan tetapi juga dapat dijadikan sebagai fakta awal bahwa perkembangan ekonomi syariah, salah satunya dilihat dari perkembangan bank syariah di Timur Tengah, tidak hanya tumbuh sebagai hal yang driven dari proses ekonomi semata. Tapi juga didorong oleh proses budaya. Dalam konteks ini kemudian pertanyaan diajukan, bagaimana perkembangan ekonomi syariah di Timur Tengah? Apakah perkembangan pesat ekonomi syariah di Timur Tengah didorong oleh akar historis Arab sebagai kesatuan modal kultural atau lebih didorong oleh proses ekonomi yang kapitalistik. Meski relatif baru, merujuk Nurus Shalihin, ekonomi Islam sebagai disiplin ilmu telah menjadi pembeda bagi ekonomi konvensional. ${ }^{3}$ Ini pula yang menjadi co-factors berkembangnya ekonomi syariah di tingkat global, termasuk Arab Saudi. Karena itu, maka kajian ini akan concern membahas

${ }^{1}$ Faisal Alnori and Faisal Alqahtani, "Capital Structure and Speed of Adjustment in Non-Financial Firms: Does Sharia Compliance Matter? Evidence from Saudi Arabia,” Emerging Markets Review 39 (June 1, 2019): h. 1, https://doi.org/10.1016/j.ememar.2019.03.008.

2 T. Kenn Gaither and Ali Jamal Al-Kandari, "The Cultural-Economic Model and Public Relations in the Middle East: An Examination of the Islamic Banking System in Kuwait," Public Relations Review 40, no. 1 (March 1, 2014): h. 1, https://doi.org/10.1016/j.pubrev.2013.11.003.

${ }^{3}$ Nurus Shalihin $\left(1^{*}\right)$ (1) Universitas Islam Negeri Imam Bonjol $\left(^{*}\right.$ ) Corresponding Author, "Fenomenologi-Ekonomi Islam: Lit Review Atas Epistemologi Ekonomi Islam Masudul Alam Choudhury | Shalihin | AL-FALAH : Journal of Islamic Economics," h. 169, accessed May 21, 2019, http://journal.staincurup.ac.id/index.php/alfalah/article/view/299. 
isu-isu historis dan aktual bagaimana perkembangan ekonomi syariah di Timur Tengah. Dengan harapan, agar tulisan ini mampu mengisi 'gap' teoritis dan konseptual perkembangan ekonomi syariah di Timur Tengah.

\section{METODE}

Adapun metode kajian yang digunakan dalam membahas penelitian ini yaitu penelitian literatur. ${ }^{4}$ Data dalam penelitian ini didapat dengan menggunakan metode dokumentasi untuk mencari data-data tentang perkembangan sistem ekonomi syari'ah di Timur Tengah, antara lain yang bersumber dari buku, jurnal, internet dan makalah. Metode analisis data yang digunakan adalah induktif, deduktif, dan analisis deskriptif. Penelitian ini merujuk pada model yang ditawarkan oleh Patrick Colm Hogan, dimana prinsip umum dari model yang ditawarkannya lebih concern pada pengkajian teks sebagai sumber data sekunder. ${ }^{5}$ Praktek penelitian ini, diawali dengan pemetaan literatur yang dapat dijadikan sebagai data sekunder. Kemudian, mencari literatur yang mengkaji bagaimana perkembangan ekonomi syariah di Timur Tengah, dari berbagai perspektif. Sederhananya, model Hogan ini berusaha menangkap polemik teoritis, dan interpretasi sejarah bagaimana perkembangan bank syariah di Timur Tengah tersebut berlangsung.

\section{HASIL DAN PEMBAHASAN}

\section{Ekonomi Syariah di Timur Tengah: Bentuk dan Perkembangannya Pelabuban Dagang}

Sebelum lahirnya era minyak pada awal ke-20, kawasan Teluk utamanya di pesisir pantai selatan, berperan sebagai jalur penghubung ke pasar-pasar India dari Barat dan Somalia dari Timur. ${ }^{6}$ Salah satunya Aden, sebuah pelabuhan alamiah Yaman, di mana kapal-kapal dari Ethiopia dan India berlabuh. Jalur timur melalui pesisir pantai semenanjung Arab bagian selatan dan hingga teluk Persia merupakan jalur penguhubung melalui lautan dari Yaman ke Irak dan menerukan melalui darat ke Syam. Di jalur itu, para pedagang melintasi pasarpasar Yaman, Irak, Palmyra, dan Syiria. Di setiap wilayah mereka menjual komoditas yang tidak ada di sana dan juga membeli komoditas wilayah itu untuk dibawa ke wilayah-wilayah lain. Oleh karena beberapa faktor, untuk sementara waktu, perkembangan ekonomi kawasan ini bisa dibilang stagnan dan luput dari perhatian dunia.

\footnotetext{
${ }^{4}$ Sugiyono, Metode Penelitian Kuantitatif, Kualitatif, Dan ReD (Bandung: Alfabeta, 2014), h. 240

5 Colm Hogan Patrick, Philosophical Approaches to the Study of Literature (Geineville: University Press of Florida, 2000), h. 12.

${ }^{6}$ Philip K. Hitti, History of the Arabs: From the Earliest Times to the Present (Jakarta: Serambi Ilmu Semesta, 2010), h. 7
} 
Salah satu faktornya adalah sukar dijangkaunya oleh para ekspedisi dagang, utamanya dari Eropa. Untuk menjangkau kawasan Teluk, para ekspedisi yang berasal dari Eropa dapat melalui tiga jalur. Pertama melalui daratan, yaitu jalur Sutra dari Allepo (Syiria) menuju teluk Persia (Irak) dan kemudian melanjutkan ekspedisi dagangnya ke Asia. Begitu pula ekspedisi dari Asia ke wilayah Eropa maupun Afrika bagian utara. Kedua, para ekspedisi dari Eropa dapat melalui semenanjung Harapan di Afrika bagian selatan, namun rute perjalanan laut yang terlalu jauh memakan waktu dan biaya yang tak sedikit. Jalur ketiga adalah melalui semenanjung Sinai di Mesir yang memisahkan Laut Mediterania dan laut Merah. Para ekspedisi mengosongkan kapalnya terlebih dahulu dan mengangkutnya melalui darat.

Kebuntuan lajur perdagangan ini kemudian terpecahkan setelah digalinya terusan Suez di semenanjung Sinai pada tahun 1870 oleh Perancis. Pesisir bagian selatan semenanjung menjadi lebih ramai dan fungsi pesisir pantai bagian selatan sebagai pelabuhanpun semakin meningkat. Peningkatan jumlah kapal-kapal ekspedisi dari Eropa utamanya Inggris, Perancis, Belanda dan Portugis, membawa warna perubahan yang mencolok terhadap kawasan ini. Pasalnya mereka tidak hanya berdagang atas produk revolusi Industri mereka, akan tetapi juga membawa misi Kolonialime.

Pada era kedinastian Usmani, kawasan teluk memang kurang mendapat perhatian pemerintahan pusat, bahkan bisa dibilang kawasan yang merdeka. Dampaknya secara keamanan, kawasan teluk, utamanya di pesisir pantainya tidak dapat dikontrol, apalagi, pesisir ini pada dulunya dikenal sebagai pesisir Perompak. Namun, Inggris yang menguasai pesisir teluk, berhasil mengusir kawanan perompak yang sering menganggu. Boleh dikata ada ketergantungan jaminan keamanan terhadap Inggris. Puncak atas ketergantungan keamaan tersebut, mengakibatkan negara-negara seperti Yaman, dan kawasan koloni Aden, Kesultanan Masqat dan Oman dan beberapa kerajaan kecil yang dipimpin oleh Syeikh dan daerah perwalian Otonom Qatar dan Bahrain, serta Kuwait dinyatakan sebagai negara otonom dibawah protektorat Inggris. Pernyataan pengawasan keamanan oleh Inggris tersebut ditandatangi dalam kurun tahun 1820 antara para Syeikh hingga yang terbaru 1916 oleh Qatar. Selanjutnya wilayah-wilayah dalam kawasan teluk ini satu persatu merdeka dimulai tahun $1961 .^{7}$

Konsekuensi atas perlindungan yang diberikan oleh Inggris kepada wilayah ini adalah dengan diberikannya kebebasan dagang Inggris di wilayahwilayah tersebut. Sehingga Inggris mendapat keuntungan besar atas monopoli perdagangannya. Bahkan monopoli dagangnya hingga menguasai India dan merambah Asia melalui penguasaan wilayah Teluk ini. Hingga zaman modern, setelah wilayah-wilayah teluk ini berdiri sebagai negara yang merdeka, sektor perdagangan tetap menjadi salah satu penopang perekonomian Timur Tengah.

\footnotetext{
${ }^{7}$ K. Hitti, h. 946-947
} 
Pertumbuhan pelabuhan baik secara jumlah maupun kesibukannya semakin meningkat setelah terusan Suez di Mesir berhasil dinasionalisasikan dan mempermudah jalur perdagangan antara benua. Fungsi dan peran pelabuhannya juga meningkat seiring dibukanya perdagangan bebas dunia. Bahkan baru-baru ini, Kuwait dan Irak kembali bersitegang dikarenakan niat Kuwait yang akan membangun pelabuhan di pulau Bubiyan, salah satu pulau terbesar di teluk Persia. Irak mengkhawatirkan rencana Pelabuhan Kuwait sebab berpotensi membuat sesak perairan di wilayah itu, yang juga menyulitkan pergerakan kapal memasuki Pelabuhan Irak.

\section{Minyak Bumi}

Revolusi Industri adalah anak kandung Renansiace Eropa. Ditemukannya mesin uap, pemutar turbin yang menggerakkan mesin-mesin industri membutuhkan sumber energi. Pada mulanya, mesin uap dijalankan dengan bara api dari kayu. Setelah ditemukannya batu bara, perannya digantikan olehnya. Begitu pula ketika lahir era minyak, tanpa mengenyampingkan peran batu bara hingga sekarang. Kargo-kargo perdagangan yang mulanya diangkut menggunakan perahu layar, digantikan dengan perahu-perahu Mesin yang bahan bakarnya dari batu bara dan minyak bumi.

Seiring perkembangan ilmu pengetahuan dan teknologi pada awal abad dua puluh, kebutuhan bahan bakar minyak mulai meningkat. Sementara itu, di Eropa sebagai tempat lahirnya alat-alat industri tidak dapat memenuhi kebutuhan akan minyak tersebut. Sehingga pada masa-masa ini, selain tetap berdagang, bangsa Eropa, terutama Inggris mulai mencari sumber minyak bumi yang bisa dieksploitasi untuk kepentingan pemenuhan kebutuhan industri mereka. Sumber minyak bumi-pun ditemukan di kawasan teluk dan hingga saat ini menjadi pemasok terbesar bagi kebutuhan minyak bumi dunia.

Penemuan minyak di Irak merupakan titik awal meningkatnya kepentingan bangsa-bangsa Eropa ke wilayah ini. Pada 1925 Perusahaan Minyak Irak (Iraq Petroleum Company) dibangun, dengan konsesi untuk jangka waktu tujuh puluh lima tahun. ${ }^{8}$ Dengan berdirinya kilang minyak di Irak, peningkatan pendapatan pemerintah meningkat. Dengan hasil ekspor minyaknya, untuk pertama kali memungkinkan melaksanakan pembangunan irigasi dan pengendalian banjir wilayah tersebut. Untuk lebih meningkatkan pendapatannya, pada 1950, sebuah dewan pengembangan dibentuk yang tugasnya mengontrol sebagian besar pendapatan dari minyak. Dewan ini juga bertugas untuk mengolah pendapatannya untuk kebutuhan pembangunan Irak, diantaranya; pembangunan dam-dam di anak sungai Tigris untuk pengairan lahan pertanian. ${ }^{9}$

\footnotetext{
${ }^{8}$ K. Hitti, h. 944
}

9 Albert Hourani, Sejarah Bangsa-Bangsa Muslim (Bandung: Mizan, 2000), h. 699-700 
Sumber-sumber minyak bumipun ditemukan di negara-negara lain seperti di Iran, Kuwait, Arab Saudi dan beberapa negara di kawasan bagian utara benua Afrika yang cakupannya masih di wilayah Timur Tengah. Sehingga produksi minyak mentah dunia didominasi oleh kawasan ini. Faktanya, pada tahun 1970, kawasan ini memasuk 60\% kebutuhan dunia. ${ }^{10}$ Di lain sisi, bangsa Eropa dan Amerika merupakan konsumen terbesar dunia. Dunia mengamini bahwa minyak, hingga saat ini merupakan komiditi ekspor menjanjikan yang membawa perubahan dan perkembangan ekonomi yang mencolok bagi negara asalnya.

Akan tetapi, sejak awal, konsesi-konsesi eksploitasi minyak, penyulingannya dan ekspornya, dilakukan oleh perusahaan-perusahaan Asing. Sebagian besar kegiatan eksplorasi tersebut dikendalikan oleh sejumlah kecil perusahaan-perusahaan yang telah memegang monopoli terhadap industri. Sebagian besar minyak tersebut diekspor ke negeri-negeri Barat. Di luar minyak itu sendiri, kontribusi negeri-negeri setempat hanya terletak pada para pekerja tingkat rendah, terampil dan non terampil dan terbatas jumlahnya, karena penyulingan dan pemprosesan minyak tidak menuntut banyak tenaga kerja. Jelang 1960-an situasi berubah.

Makin banyak lelaki lokal yang dipekerjakan pada tugas-tugas yang membutuhkan keahlian tinggi. Pembagian keuntungan antara perusahaan dan negeri setempat pun mulai berubah, walau presentasinya masih sangat kecil. Semenjak tahun 1950, tekanan dari negeri-negeri penghasil melakukan upaya perubahan di dalam kesepakatan yang di buat antara negara penghasil dan perusahaan pengeksploitasi, hingga saham mereka menjadi $50 \%$ dari pendapatan bersih perusahaan-perusahaan tersebut. Usaha negeri-negeri penghasil nampaknya mulai membuahkan hasil, setelah 1960, mereka (tak hanya yang ada di Timur Tengah) secara bersama-sama masuk ke dalam sebuah organisasi negara pengekspor minyak (OPEC), yaitu sebuah organisasi yang bertujuan memajukan bersama dalam negosiasi dengan perusahaan-perusahaan minyak besar. Di dalam OPEC, mereka saling bekerjsama. Jalan semakin terbuka untuk sebuah proses baru yang akan berakhir dengan pengambilalihan fungsi perusahaan-perusahaan oleh negeri-negeri tersebut, setidaknya dalam kegiatan produksi. ${ }^{11}$

Munculnya kilang-kilang minyak di sebagian wilayah Timur Tengah, memang merangsang perekonomian negeri tersebut. Peningkatan devisa negara mampu membiayai peningkatan pembangunan negara secara signifikan. Namun, tidak semua negeri mempunyai harta yang disebut black gold (Emas Hitam). Sehingga pada perkembangannya, terdapat perbedaan sangat mencolok di bidang ekonomi antara negeri penghasil dan negeri non-penghasil, yaitu

${ }^{10}$ Ewan E. Anderson, The Middle East; Geography and Geopolitics (London: Routledge, 2000), h. 285

${ }^{11}$ Hourani, Sejarah Bangsa-Bangsa Muslim, h. 704-705 
negeri kaya dan negeri miskin. Si kaya tidak menutup mata akan kemiskinan negeri non-penghasil minyak. Faktanya, pada tahun 1970- an, beberapa lembaga seperti organisasi negeri-negeri Arab pengekspor minyak (OAPEC) dan lembaga swasta oleh Kuwait, Arab Saudi dan Abu Dhabi memberi bantuan yang sangat besar bagi negeri-negeri berkembang di sekitar wilayah mereka. Pada 1979, sekitar $\$ 2$ miliar diberikan melalui berbagai bidang. Bantuan tersebut terbilang kecil dibanding kekayaan mereka, karena jumlah tersebut hanya sekitar 2,9\% dari hasil kotor nasional (GNP) negeri-negeri penghasil minyak. ${ }^{12}$

Dan begitupula di Timur Tengah Minyak Sebagai Senjata Politik dan merupakan sentral perekonomian dunia saat ini. Kestabilan ekonomi akan terganggu jika sumber energi yang menghidupinya terganggu. Konsekuensi -nya, kestabilan keamanan kilang-kilang minyak harus dijaga. Jika tidak, maka pasokan minyak bumi terganggu dan inflasi harganya terganggu dan inflasi eknomi duniapun ikut serta. Dengan ketergantungan ini, penguasaan atas minyak bumi berarti penguasaan terhadap perekonomian dunia. Itu yang saat ini terjadi, yang menjadikannya senjata politik dunia.

Peristiwa geopolitik yang mempengaruhi pasokan minyak berikut harganya sudah kerap terjadi. Embargo minyak oleh Liga Arab pada perang Arab-Israel pada tahun 1974 telah menimbulkan krisis minyak dunia dan pertama kalinya minyak dipakai sebagai senjata politik. Revolusi Iran pada 1979 yang diikuti perang Irak-Iran telah menciptakan krisis minyak kedua. Invasi Irak ke Kuwait pada 1990 juga sempat membuat harga minyak meroket. Lebih ekstrimnya, terjadi pada awal tahun 2003, dimana invasi atas Irak oleh Amerika yang bebarengan dengan krisis politik di Venezuela dan Nigeria menyebabkan kekurangan pasokan minyak dunia lebih dari empat juta barel per hari.

Setelah minyak digunakan sebagai senjata politik oleh negara-negara Arab pada perang Arab-Israel tahun 1973-1974, Amerika Serikat dan sekutunya merancang skenario memecah belah negara-negara Timur Tengah, sehingga, tidak bersatu untuk menggunakan minyak sebagai senjata politik. Arab Saudi, pemilik cadangan minyak terbesar di dunia, dimanjakan Amerika Serikat dengan berbagai bentuk bantuan persenjataan canggih, penasihat militer, instruktur dan teknisi. Melalui operasi Badai Gurun, Amerika Serikat juga melindungi Arab Saudi dan Kuwait dari invasi Irak pada 1990. Sebagai kompensasi, Amerika Serikat meminta bantuan uag minyak Saudi untuk membiayai operasi CIA untuk menggulingkan rezim-rezim kiri yang didukung Uni Soviet di Afghanistan, Nikaragua, dan lain-lain. Para pengambil kebijakan Amerika Serikat sebenarnya enggan bermitra dengan rezim monarki yang dianggapnya "antidemokrasi", bersepakat bahwa akses terhadap minyak Saudi adalah bagian dari agenda nasional yang harus dipertahankan. Amerika Serikat secara tidak langsung mengobarkan perang Irak-Iran pada 1980. Ketika Irak menginvasi Iran pada

12 Hourani, h. 780 
September 1980, Washington menyatakan netral dan menjatuhkan embargo kepada pihak-pihak yang bertikai.

Ketika Iran berada di atas angin dan mengancam kepentingan minyak Amerika Serikat di Arab Saudi dan Kuwait, Washington diam-diam menyokong Irak dengan memberinya pinjaman uang, dukungan intelijen, dan transfer senjata secara gelap. Kawasan Timur Tengah yang kaya minyak lantas menjelma sebagai negara yang terpecah-pecah. Arab Saudi tidak mungkin bisa mengambil kembali peran yang pernah dimainkannya pada 1973 yang kompak menghukum Amerika Serikat melalui embargo minyak karena membela Israel dalam perang Arab-Israel. Arab Saudi yang sudah berada di bawah kontrol Washington tidak mungkin bisa mencegah invasi Amerika Serikat ke Irak pada 2003. Arab Saudi juga tidak bisa berbuat apa-apa ketika Israel menyerang Libanon pada 2006. Bersama negara-negara Arab lain, Arab Saudi diam-diam menyokong dijatuhkannya sanksi terhadap Iran yang menolak menghentikan program nuklirnya.

Dalih apa pun bisa digunakan, tapi motif yang sebenarnya adalah minyak, masih sangat membekas dalam ingatan, dengan dalih menyimpan senjata pemusnah massal, Amerika Serikat menumbangkan Saddam Hussein dan menguasai Irak, pemilik cadangan minyak terbesar ketiga di dunia. Publik Amerika Serikat sadar bahwa motif utama invasi Irak adalah minyak, sebagaimana terungkap dalam poster-poster protes mereka yang berbunyi "No Blood for Oil". Ternyata, senjata pemusnah massal yang dibuat alasan Bush tidak pernah terbukti. Belakangan di tengah ancaman serangan Israel dan Amerika Serikat terhadap Iran bila Iran tidak menghentikan program nuklirnya juga menyingkapkan ada upaya lewat diplomasi minyak. Iran dikabarkan telah bersiap-siap menggunakan minyak sebagai senjata diplomatik dengan menutup Selat Hormuz jika terjadi konflik dengan Barat. Teheran memiliki keuntungan diplomatik dengan menutup jalur kapal-kapal untuk pengiriman minyak di selat yang memisahkan Teluk Persia dan Teluk Oman tersebut.

Nampaknya, Amerika seakan takut dan berpikir ulang untuk menyerang Iran sebagai negeri pembangkang atas usahanya mengembangkan senjata Nuklir. Pertama, perlu diperhatikan bahwa untuk melaksanakan penyerangan militer, tentunya Amerika membutuhkan dana yang besar, padahal krisis ekonomi yang melanda paman syam saat ini merupakan imbas dari pembiyaan invansi militernya ke kawasan Timur Tengah, utamanya Irak dan Afgahnistan. Kedua, Amerika serikat merupakan konsumen terbesar minyak dunia, dengan begitu ia sangat tergantung dengan produsen terbesar minyak dunia yang letaknya di kawasan teluk Arab. Jikapun Amerika menyerang Iran, maka akan mengusik ketentraman kawasan selat Hormus dimana kilang-kilang minyak banyak di sekitar wilayah tersebut. Amerika sadar betul bahwa hal tersebut akan membuat malapetaka perekonomian dunia, termasuk negerinya sendiri.

Sejumlah negara di Timur Tengah berlomba untuk menerbitkan sukuk. Arab Saudi yang selama ini belum tertarik pada sukuk, terus didorong untuk 
menerbitkan sukuk perdana pada awal 2012. Arab Saudi berpotensi menjadi pemimpin penerbitan sukuk di dunia, tetapi hal ini terkendala dengan belum adanya dukungan pemerintah. Meski sudah ada bursa efek Saudi (Tadawul) sejak 2009, sukuk terus ditahan di pasar uang setempat. Menurut Saudi Arabia Moneter Agency, pada kuartal kedua 2011, cadangan devisa asing di bank sentral naik terus menjadi 1,86 triliun riyal Saudi dari 1,75 triliun riyal pada kuartal pertama.

Perusahaan dan eksportir minyak terbesar di dunia, Saudi Aramco, sebelumnya telah melakukan pembicaraan untuk penambahan dana di pasar keuangan termasuk melalui sukuk. Namun, pembicaraan tersebut belum terwujud hingga sekarang. Baru-baru ini, Bank Sentral Bahrain mengumumkan penerbitan sukuk Al-Salam senilai 18 juta dinar Bahrain. Penerbitan ini telah kelebihan penawaran 183 persen. Sukuk ini akan jatuh tempo pada 28 Maret 2012 dengan imbal hasil 1,25 persen. Penerbitan sukuk Al-Salam yang dilakukan bank sentral ini merupakan penerbitan resmi dari pemerintah kerajaan Bahrain. Pertumbuhan pasar sukuk memang merupakan yang tercepat di keuangan syariah.

Bahkan, pertumbuhan pasar sukuk juga yang paling cepat di antara segmen lain di pasar keuangan global. Hal itu diungkapkan Kepala Syariah Komplien di Bank Al-Khair Bahrain dalam bukunya berjudul "Global Sukuk and Islamic Securitisation Market-Financial Egineering and Produk Innovation".Menurutnya, sukuk telah menarik komunitas bisnis di seluruh dunia. "Sukuk telah meletakkan keuangan syariah sebagai sebuah industri yang layak dan menjadi aset tidak hanya bagi negara Muslim tapi juga menjadi bagian dari pasar keuangan internasional. Ketua Financial Grup BMG, Basil AlGhalayini, mengatakan penerbitan instrumen dengan pendapatan tetap atau sukuk akan memberikan bentuk pembiayaan baru. Penerbitan sukuk pemerintah akan baik untuk pasar modal dalam negeri sebagai investasi yang aman. "Ada beberapa proyek infastruktur seperti bandara, kereta api yang memenuhi syarat dibiayai sukuk. ${ }^{13}$

\section{Teori Ekonomi Islam di Timur Tengah \\ Ekonomi Islam di Zaman Rasulullah}

Pada umumnya keadaan ekonomi Islam pada masa Rasul ini tidak berbeda dengan keadaan ekonomi pada masa pra Islam di mana perekonomian didominasi oleh bidang perdagangan. Karena situasi dan kondisi pada waktu itu yang kerap dipenuhi dengan peperangan antara kaum muslimin dengan nonmuslim, maka aktivitas perdagangan ini tidak sehebat pada masa pra Islam. Ibn Hisyam, Sejarawan muslim abad ke-3 Hijriyah, mencatat tidak kurang dari 20 perang telah terjadi antara kaum muslimin dan non-muslim selama pemerintahan Islam di Madinah.

$13 \mathrm{http} /$ /www.ekonomisyariah.org/author/ekonomis/ diakses oktober 2017 
Namun hal ini tidak berarti ekonomi Islam tidak memiliki nilai tambah jika dibandingkan dengan peradaban Arab pra Islam. Karena Rasulullah, setelah tiba di Madinah dan menjadi pemimpin pemerintahan, di sana telah melakukan langkah-langkah strategis dan pintar dengan meletakkan dasar-dasar ekonomi dan keuangan negara berdasarkan prinsip dan nilai-nilai yang digariskan dalam Al-Qur'an sebagai sumber nilai dalam kehidupan masyarakat Islam, termasuk dalam bidang ekonomi ini. ${ }^{14}$

Prinsip dan nilai-nilai ekonomi Islam yang menjadi dasar penerapan ekonomi dan keuangan yang diterapkan Rasulullah Saw dan para sahabatnya secara umum ada dua yaitu: Pertama, Manusia itu terdiri dari dua unsur, yaitu jasmani dan rohani atau materiil dan spiritual sebagai satu kesatuan yang tidak terpisahkan. Maka dari itu, umat Islam tidak diperintahkan untuk memikirkan sisi akhirat saja dengan mengesampingkan sisi dunianya. Dalam hal ini Allah Swt berfirman:

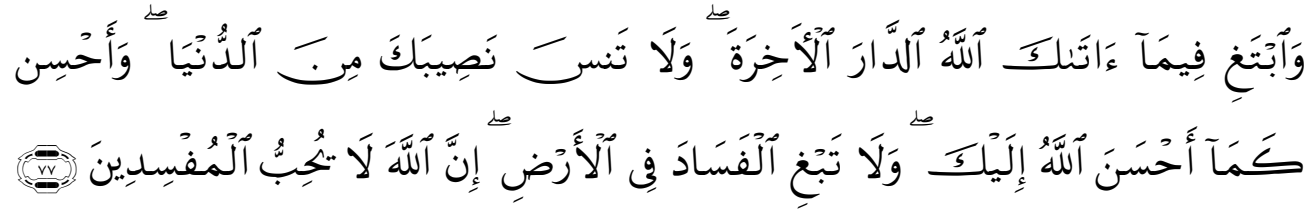

Artinya:Dan carilah pada apa yang telah Allah anugerabkan kepadamu kebahagiaan di akbirat dan janganlah kamu melupakan bagianmu dari kebahagiaan dunia dan berbuat baiklah sebagaimana Allah telab berbuat baik kepadamu.

Kedua, Dalam melakukan aktivitas ekonomi, baik sebagai konsumen maupun produsen, umat Islam tidak diperkenankan melakukan hal-hal yang membawa kerusakan baik untuk dirinya sendiri maupun orang lain. Sebagai konsumen seperti halnya menghilangkan unsur riba dalam perekonomian. Pada masa Islam, institusi ekonomi baru dilahirkan. Institusi ini disebut dengan Baitul Mal. Pada masa Rasul yang dilanjutkan dengan masa khalifah Abu Bakar, Baitul Mal yang berfungsi untuk mengumpulkan keuangan Negara untuk kepentingan masyarakat ini berlokasi di masjid. Sedangkan pada masa Umar bin Khattab, Baitul Mal sudah merupakan bangunan tersendiri yang dibangun di Madinah sebagai pusat negara dan di provinsi-provinsi lainnya sebagai cabangnya. Adapun sumber keuangannya ada yang berasal dari zakat, baik zakat fithrah maupun zakat harta. Zakat fithrah ini berupa makanan-makanan pokok yang dikeluarkan oleh setiap muslim sebelum menunaikan shalat idul fithri. Sedangkan zakat harta adalah zakat yang dikeluarkan oleh kaum muslimin jika harta mereka telah sampai pada nishab, yaitu jumlah minimal harta yang diwajibkan pada seorang muslim untuk membayar zakat. Hasil pengumpulan zakat ini diberikan kepada orang-orang yang berhak menerimanya. 2013), h. 4

${ }^{14}$ Machfud Syaifudin, Dinamika Peradaban Islam (Yogyakarta: Pustaka Ilmu Yogyakarta, ${ }^{15}$ Q.S. Al-Qashas: 77 


\section{Ekonomi Islam di Zaman Khulafaurasyidin}

Dalam hal pendistribusian harta dari Baitul Mal, pada masa Rasul yang dilanjutkan dengan masa khalifah Abu Bakar 11-13 H (632-634 M), konsepnya masih sederhana yaitu bahwa setiap orang Islam harus mendapatkan haknya yang sama dan adil sehingga kemiskinan dapat diminimalisir semaksimal mungkin. Maka dari itu, harta dari Baitul Mal selalu habis karena langsung didistribusikan kepada kaum muslimin untuk memenuhi kebutuhan hidup mereka sehari-hari.

Pada masa Umar bin Khattab 13-23 H (634-644 M), karena semakin luasnya wilayah ekspansi Islam dan pendapatan negara mengalami peningkatan yang signifikan, harta Baitul Mal tidak langsung dihabiskan tetapi sebagiannya disimpan baik untuk pembayaran gaji pegawai, untuk keadaan darurat maupun kebutuhan-kebutuhan mendesak lainnya. Oleh karena itu, Umar pun menunjuk Abdullah bin Irqam sebagai bendahara negara dan Abdurrahman bin Ubaid Al Qari dan Muayqab sebagai wakilnya. ${ }^{16}$

Pada masa pemerintahan Utsman bin Affan 23-35 H (644-656 M), keadaan ekonomi Islam tidak mengalami perubahan yang signifikan dan sebagaimana khalifah sebelumnya, ia tetap memperhatikan sistem pemberian bantuan dan santunan kepada masyarakat. Namun, banyak kebijakan Utsman yang menguntungkan keluarganya sehingga menimbulkan benih kekecewaan yang mendalam pada sebagian besar kaum muslimin yang mengakibatkan timbulnya kekacauan politik dan berakhir dengan terbunuhnya Usman. Ali bin Abi Thalib 35-41-H (656-661 M), sebagai khalifah terakhir, meskipun negara berada dalam suasana politik yang tidak menentu, tetap berusaha menerapkan ekonomi Islam dengan sebaik-baiknya demi kesejahteraan umat Islam. Dalam suatu riwayat, sebagaimana ditulis Adiwarman, Ali memberikan sumbangan sebesar 5000 dirham setiap tahun. Ia juga pernah memenjarakan Gubernur Ray yang dianggapnya melakukan tindak pidana korupsi. ${ }^{17}$

Ekonomi Islam di Zaman Bani Umayyah 41-132 H (661-750 M)

Berbicara tentang kondisi ekonomi pada masa Dinasti Bani Umayyah, keberadaan Baitul Mal merupakan bukti adanya perkembangan ekonomi pada masa itu. Eksistensi Baitul mal pada masa Dinasti Bani Umayyah sangat berperan sekali di sebabkan penaklukkan yang di lakukan sangat luas sekali, ke Barat sampai ke Afrika Utara Andalusia dan ke timur sampai ke India dan keperbatasan Cina. Daerah yang ditaklukkan ini terkenal dengan kekayaan dan kesuburan tanahnya.

Khalifah dan para pejabat Negara serta militer waktu itu banyak memperoleh harta rampasan perang dan tanah-tanah yang subur dari tuan-tuan

16 Adiwarman Azwar Karim, Sejarah Pemikiran Ekonomi Islam (Jakarta: Raja Garafindo Persada, 2004), h. 60

17 Azwar Karim, h. 63-64 
tanah besar Bizantium yang telah melarikan diri bersama tentara kerajaan yang telah dilumpuhkan. Pemerintahan memperoleh pajak-pajak dari daerah-daerah yang ditaklukkan tersebut. Pemasukan keuangan negara berupa Kharaj, Jizyah, Usyur, zakat dan lainnya. Ada tanah diolah dengan memakai tenaga buruh dari para petani, ini termasuk sumber pemasukkan pokok keuangan negara. Sistem sewa (leases) ini ditirukan dari sistem emphyteusis dari Bizantium. ${ }^{18}$

Pada masa khalifah Abdul Malik bin Marwan dicetak uang sebagai alat tukar yang dibuat dari emas dan perak, serta dihiasi dengan khat ayat Al-Qur'an. Mata uang ini berbeda dengan kerajaan Bizantium ataupun dirham kerajaan Persi. Percetakan uang kembali sebagai ciri khas bagi khalifah bani Umayyah pada masa pemerintahan Abdul Malik ini menunjukkan banyaknya orang kaya melimpah ruah di kota-kota bahkan di padang pasir. ${ }^{19}$ Melihat kondisi perekonomian yang demikian dapat dikatakan, bahwa perekonomian pada saat itu sangat baik dan maju Dengan gambaran yang diberikan di atas, kita tahu begitu besarnya kemajuan di bidang ekonomi masa Bani Umayyah yang menjadikan Islam sebagai kekuatan adi daya di masa itu.

\section{Ekonomi Islam di Zaman Bani Abbasiyah 132-232 H (750-857 M)}

Pada masa Abbasiyah terdapat kemajuan di bidang perekonomian Usaha-usaha. Bani Abbas di bidang pembangunan ekonomi negara dapat dikatakan singguh luar biasa, sehingga dalam waktu yang relatif singkat terjadi pertumbuhan ekonomi yang pasti. Al-Mansur dan khalifah kedua dinasti ini, adalah seorang yang banyak menaruh perhatian terhadap penggalian potensipotensi alamiah yang terdapat di wilayah kekuasaannya. Setidaknya ada tiga sektor penting yang dikembangkan, pada masa Bani Abbas ini Yakni pertanian, industri dan perdagangan.

Pada sektor pertanian adanya perhatian yang besar terhadap pembangunan pertanian ditandai dengan suatu gerakan revolusi hijau didaerahdaerah subur dilembah sungan dajlah dan effrat. Gerakan ini dimulai dengan pembangunan bendungan-bendungan dan kanal diberbagai tempat, sehinggah air melimpah menelusuri lembah dan daratan rendah yang sangat luas, yang menurut catatan ak-Baghdadi mencapai 36.000 .000 jarib (sekitar 9.000.000 Hektar). Kemudian untuk mempermudah angkutan pertanian, dibangun sarana perhubungan ke segaka penjuru, baik melalui darat maupun sungai. ${ }^{20}$

Dan begitupula pada sector industry pada prinsipnya mengacu pada penggalian sumber daya alam dengan memanfaatkan tenaga-tenaga kerja manusia dalam pembuatan bahan baku yakni dalam bidang penambangan

${ }_{18}$ Bernars Lewis, Bangsa Arab Dalam Lintasan Sejarah Jakarta: PIJ Press, 1988 (Jakarta: PIJ Press, 1988), h. 61

19 Muhammad Tayyib an-Najar, Mubadarah Fi At-Tarikh Al-Alam Al-Islami (Kairo: Maktabah Madani, tt), h. 236

${ }^{20}$ Hassan Ibrahim Hasan, Tarikh Al-Islam as-Siyasi Wa Ad-Dini Wa as- Tsaqafi Wa AlIjtima'i, 1 (Kairo: Maktabah an-nahdhah, 1964), h. 304 
sekalipun taraf perkembangan undustri Bani Abbas masih tergolong konvensional akan tetapi, pada zaman ini sudah dinilai cukup maju. Contohnya pemerintah pemerintah telah mencapai sukses besar dan sangat strategis bagi pemenuhan kebutuhan pembangunan dan konsumsi masyarakat. ${ }^{21}$ Apabila kita lihat di sector perdagangan dikarenakan tempatnya yang startegis yaitu di kota Baghdad maka kondisi pasar sangat ramai, menggambarkan betapa luasnya hubungan dagang yang telah dikembangkan oleh pemerintah Bani Abbas. ${ }^{22}$

Pemikiran ekonomi Islam diawali sejak Muhammad SAW dipilih sebagai seorang Rasul (utusan Allah. Rasulullah SAW mengeluarkan sejumlah kebijakan yang menyangkut berbagai hal yang berkaitan dengan maslah kemasyarakatan, selain masalah hukum (Fiqh, politik (siyasah), juga masalah mu'amalah. Masalah-masalah ekonomi umat menjadi perhatian raasul, karena masalah ekonomi merupakan pilar penyangga keimanan yang harus diperhatikan. Sebagaimana yang diriwayatkan oleh Muslim, rasulullah bersabda," kemiskinan membawa orang kepada kekafiran". Maka upaya untuk mengentas kemiskinan merupakan bagian dari kebijakan-kebijakan sosial yang dikeluarkan rasulullah SAW.

Selanjutnya kebijakan-kebijakan Rasulullah SAW menjadi pedoman oleh para penggantinya Abu Bakar, Umar bin Khatab, Usman bin Affan dan Ali bin Abi Thalib dalam memutuskan masalah-masalah ekonomi. Al-qur'an dan Hadist digunakan sebagai dasar teori ekonomi oleh para khalifah juga digunakan oleh para pengikutnya dalam menata kehidupan ekonomi Negara. ${ }^{23}$ Pada masa rasulullah, sumber pendapatan Negara berasal dari zakat dan ghanimah. Kedua hal ini, memaksa kaum muslim untuk secara serius memikirkan berbagai realitas ekonomi yang mereka rasakan. Masa Ekspansi Islam, pada masa Abu bakar dalam bidang ekonomi dan keuangan ada masalah besar yang muncul: Jumlah harta rampasan perang dari sekian banyak tentu saja menyebabkan terjadinya surplus pada kas Negara dan begitupula pada masa ini, terdapat perbedaan dengan masa sebelumnya yaitu pada masa rasulullah karena pada zaman rasulullah setiap adanya permasalahan langsung dijawab oleh Rasulullah akan tetapi setelah wafatnya Rasul dan dengan segala permasalahan yang ada dan bermunculan maka pada masa ini lahirlah sejumlah ijtihad baru dalam kaitan pengembangan berbagai subsistem, diantaranya subsistem ekonomi dan keuangan. ${ }^{24}$

Kemudian adanya konflik dikalangan internal umat Islam yang muncul pada masa akhir masa khalifah Utsman bin Affan dan Ali bin Thalib sedikit menghambat laju ekonomi. Pada masa bani Umayyah konflik politik itu relative bisa direndam dan Islam melaju kembali sampai memasuki wilayah Eropa

${ }^{21}$ Philip K. Hitti, The History of The Arabs (London: The Macmillian Press, 1974), h. 345

${ }^{22}$ Ibrahim Hasan, Tarikh Al-Islam as-Siyasi Wa Ad-Dini Wa as- Tsaqafi Wa Al- Ijtima'i, h. 318

${ }^{23}$ Heri Sudarsono, Konsep Ekonomi Islam (Yogyakarta: Ekonisia, 2007), h. 117

${ }^{24}$ Ahmad Izzan, Referensi Ekonomi Syariah (Bandung: Remaja Rosdakarya, 2006), h. 32 
melalui Andalusia, Palermo dan Sicilia. Dan ketika khalifah Bani Umayyah runtuh pada tahun $132 \mathrm{H}$, khalifah bani Abbasiyah yang menggantikan terus melanjutkan ekspansi Islam. Akan tetapi, pada masa ini yaitu pada mas khulafatur rasyidin, adanya perluasan wilayah yang menimbulkan banyak masalah dalam berbagai bidang, termasuk ekonomi dan keuangan. ${ }^{25}$

\section{Ekonomi Islam pada Zaman Bani Abbasiyah}

Akan tetapi, Pada masa Khilafah Kerajaan Usmani atau kerajaan Turki Usmani berbeda dengan kerajaan-kerajaan sebelumnya, kerajaan ini mengalami kemunduran pada abad ke 17 hingga abad ke 18. Kerajaan ini dalam dalam posisi tertekan dengan regergasi ekonomi, pemberontakan rakyat dan kekalahan militer. Munculnya kemunduran Turki Usmani diawali dari kekacauan pemerintahan yang dipimpin oleh Sultan Muhammad III, pengganti Murod III . keadaaan ini terus berlangsung pada masa pemerintahan Ibrahim (1640-1648) dan puncak kehancuran pemerintah ini pada abad ke 17 terjadi pada masa Mustofa (1617-1618 M). ${ }^{26}$

Ketidakstabilan politik kerajaan Turki Usmani pada abad ke 17 memberikan pengaruh besar terhadap perkembangan ekonomi Negara. Akibat perang yang tidak pernah berhenti maka, perekonomian Negara merosot, pendapatan berkurang akan tetapi, belanja Negara sangat besar termasuk biya perangdan kemudian di Eropa muncullah kapitalisme dengan munculnya kapitalisme di eropa semakin menurunnya prosuksi industry kerajaan masyarakat Turki. Dengan cara para pedagang eropa membeli bahan mentah dari Turki kemudian, mereka mengolahnya di Eropa. Setelah itu dibawa dan dipasrkan di Turki dengan diskon yang tinggi dan kualitas lebih bagus, dengan cara ini banyak pedagang Turki yang menggulung tikar.dan begitu pula, pada nilai tukar mata uang Turki terhadap mata uang asing juga turun drastis, meskipun pemerintah telah berupaya untuk mengandalikan harga dan nilai inflasi. Dan begitupula harga makanan yang ikut naik secara bertahap, dengan melihat situasi perekonomian yang serba sulit ini memaksa kerajaan untuk mengevaluasi nilai mata uangnya kembali.

\section{SIMPULAN}

Penemuan minyak di Irak merupakan titik awal meningkatnya kepentingan bangsa-bangsa Eropa ke wilayah ini. Pada 1925 Perusahaan Minyak Irak (Iraq Petroleum Company) dibangun, dengan konsesi untuk jangka waktu tujuh puluh lima tahun. Dengan berdirinya kilang minyak di Irak, peningkatan pendapatan pemerintah meningkat. Dengan hasil ekspor minyaknya, untuk pertama kali memungkinkan melaksanakan pembangunan irigasi dan pengendalian banjir wilayah tersebut. Untuk lebih meningkatkan

25 Izzan, h. 15-19

26 Ah. Zakki Fuad, Negara Islam Atau Negara Nasional (Kediri: Jenggala Pustaka Utama, 2010), h. 210 
pendapatannya, pada 1950, sebuah dewan pengembangan dibentuk yang tugasnya mengontrol sebagian besar pendapatan dari minyak. Dewan ini juga bertugas untuk mengolah pendapatannya untuk kebutuhan pembangunan Irak, diantaranya; pembangunan dam-dam di anak sungai Tigris untuk pengairan lahan pertanian.]

\section{Referensi:}

Alnori, Faisal, and Faisal Alqahtani. "Capital Structure and Speed of Adjustment in Non-Financial Firms: Does Sharia Compliance Matter? Evidence from Saudi Arabia.” Emerging Markets Review 39 (June 1, 2019): 50-67. https://doi.org/10.1016/j.ememar.2019.03.008.

Nurus Shalihin, Muhammad Sholihin, "Fenomenologi-Ekonomi Islam: Lit Review Atas Epistemologi Ekonomi Islam Masudul Alam Choudhury | Shalihin | AL-FALAH : Journal of Islamic Economics." Accessed May 21, 2019.

http://journal.staincurup.ac.id/index.php/alfalah/article/view/299.

Azwar Karim, Adiwarman. Sejarah Pemikiran Ekonomi Islam. Jakarta: Raja

Garafindo Persada, 2004.

E. Anderson, Ewan. The Middle East; Geography and Geopolitics. London: Routledge, 2000.

Fuad, Ah. Zakki. Negara Islam Atan Negara Nasional. Kediri: Jenggala Pustaka Utama, 2010.

Gaither, T. Kenn, and Ali Jamal Al-Kandari. "The Cultural-Economic Model and Public Relations in the Middle East: An Examination of the Islamic Banking System in Kuwait." Public Relations Review 40, no. 1 (March 1, 2014): 33-41. https://doi.org/10.1016/j.pubrev.2013.11.003.

Hourani, Albert. Sejarah Bangsa-Bangsa Muslim. Bandung: Mizan, 2000.

Ibrahim Hasan, Hassan. Tarikh Al-Islam as-Siyasi Wa Ad-Dini Wa as- Tsaqafi Wa Al- Ijtima'i. 1. Kairo: Maktabah an-nahdhah, 1964.

Izzan, Ahmad. Referensi Ekonomi Syariah. Bandung: Remaja Rosdakarya, 2006.

K. Hitti, Philip. History of the Arabs: From the Earliest Times to the Present. Jakarta:

Serambi Ilmu Semesta, 2010.

- The History of The Arabs. London: The Macmillian Press, 1974.

Lewis, Bernars. Bangsa Arab Dalam Lintasan Sejarah Jakarta: PIJ Press, 1988.

Jakarta: PIJ Press, 1988.

Patrick, Colm Hogan. Philosophical Approaches to the Study of Literature. Geineville:

University Press of Florida, 2000.

Sudarsono, Heri. Konsep Ekonomi Islam. Yogyakarta: Ekonisia, 2007.

Sugiyono. Metode Penelitian Kuantitatif, Kualitatif, Dan R\&D. Bandung: Alfabeta, 2014. 
Syaifudin, Machfud. Dinamika Peradaban Islam. Yogyakarta: Pustaka Ilmu Yogyakarta, 2013.

Tayyib an-Najar, Muhammad. Mubadarah Fi At-Tarikh Al-Alam Al-Islami. Kairo: Maktabah Madani, tt. 